\section{Tall Fescue Seedling Tolerance to Carfentrazone, Bromoxynil, Quinclorac, and Siduron}

\author{
J. Scott McElroy ${ }^{1}$ and Greg K. Breeden ${ }^{2}$ \\ Plant Sciences Department, The University of Tennessee, Knoxville, TN 37996
}

Additional index words. turfgrass establishment, weed control, herbicide injury

\begin{abstract}
Siduron and quinclorac provide limited broadleaf weed control during seeded establishment of tall fescue. Carfentrazone and bromoxynil are contact herbicides that act primarily on broadleaf, dicot species. Research was conducted to evaluate tall fescue tolerance to carfentrazone or bromoxynil when integrated into traditional siduron and quinclorac weed control programs. Quinclorac at $0.84 \mathrm{~kg} \cdot \mathrm{ha}^{-1}$ applied at seeding followed by quinclorac at $0.84 \mathrm{~kg} \cdot \mathrm{ha}^{-1} 35$ days after emergence (DAE) and quinclorac at $1.68 \mathrm{~kg} \cdot \mathrm{ha}^{-1}$ plus carfentrazone at $0.034 \mathrm{~kg} \cdot \mathrm{ha}^{-1}$ applied DAE were the most injurious to tall fescue 42 and 49 DAE. While quinclorac sequential applications reduced turfgrass groundcover 42 DAE, tall fescue recovered by 49 DAE. Injury from all quinclorac treatments persisted until 63 DAE. Bromoxynil $\left(0.28\right.$ or $\left.0.56 \mathrm{~kg}^{\cdot h^{-1}}\right)$ or carfentrazone $(0.017$ or $0.034 \mathrm{~kg} \cdot \mathrm{ha}^{-1}$ ) caused minimal injury and no decrease in turfgrass groundcover when applied 35 DAE. While siduron applied at seeding followed by (fb) bromoxynil applied 35 DAE (6.7 fb $0.56 \mathrm{~kg} \cdot \mathrm{ha}^{-1}$ ) caused minimal tall fescue injury, a decrease in groundcover was observed at 49 DAE. No tall fescue cover reduction was observed for any treatment by 63 DAE. These data indicate that bromoxynil and carfentrazone can be safely used during seeded establishment of tall fescue beginning 35 DAE with no long-term effects on turfgrass stand development.
\end{abstract}

Siduron and quinclorac are used for weed control during seeded establishment of tall fescue. Siduron is applied at planting for preemergence control of warm-season annual grasses, such as crabgrass (Digitaria spp.) species (Sherman et al., 1980). While siduron is classified as a substituted urea herbicide that classically inhibits electron transport in photosystem II, its primary mode of action is root inhibition (Vencill et al., 2002). Siduron provides preemergence control of annual grasses, but poor control of emerging annual broadleaf weeds and has little postemergence activity (Askew et al., 2003; Vencill et al., 2002).

Quinclorac can be used both pre- and postemergence for control of crabgrass species during seeded establishment of tall fescue (Askew et al., 2003; Reicher et al., 1999). Quinclorac is a substituted quinolinecarboxylic acid herbicide that mimics natural auxin, resulting in an auxin overdose and cyanide accumulation(Grossman, 1998; Grossman and Kwiatkowski, 2000). Limitations of quinclorac as a turf herbicide include lack of goosegrass [Eleusine indica (L.) Gaertn.] control and control of only a limited set of broadleaf weeds (Johnson, 1996; Vencill et al., 2002; Zawierucha and Penner, 2001).

Bromoxynil and carfentrazone have the potential to improve broadleaf weed control and complement siduron and quinclorac during

Received for publication 22 Sept. 2005. Accepted for publication 1 Nov. 2005. The authors wish to thank the East Tennessee Research and Education Center-Plant Sciences Unit farm crew for technical assistance of this research.

${ }^{1}$ Assistant professor. To whom reprints should be requested; e-mail mcelroy@utk.edu.

${ }^{2}$ Research and extension associate; e-mail gbreeden@utk.edu. seeded establishment of tall fescue. Both are contact herbicides with limited translocation that target annual broadleaf weeds. Bromoxynil inhibits photosynthetic electron transport, leading to free radical generation, and eventual plant necrosis at contact sites (Baughman et al., 1981; Vencill et al., 2002). Bromoxynil controls numerous small broadleaf weed species, including common cocklebur (Xanthium strumarium L.), morningglories (Ipomoea spp.), and pigweeds (Amaranthus spp.)(Robinson etal., 2002). However, broadleaf weed control with bromoxynil is known to decrease as the size of the plants increase (Reddy, 2001). Repeat bromoxynil applications or tank-mixtures with more potent control of large annual and perennial broadleaf weeds (Reddy, 2001, 2004).

Carfentrazone is a phenyl triazolinone herbicide that inhibits protoporphyrinogen oxidase, which induces lipid peroxidation through singlet oxygen accumulation (Dayan et al., 1997). Carfentrazone provides excellent control of velvetleaf (Abutilon theophrasti Medicus), morningglories, and smartweeds (Polygonum spp.) (Dayan et al., 1997; Mitchell and Gage, 2000). Similar to bromoxynil, carfentrazone provides excellent control of small annual weeds, but repeat applications or herbicide tank-mixtures are often needed to increase efficacy (Bean and Rowland, 2001; Gannon and Yelverton, 2004; Kelly et al., 2002). In turfgrass systems, carfentrazone is often used in mixture with $2,4-\mathrm{D}$, dicamba, and mecoprop to hasten control of numerous broadleaf weeds (Warren and Yelverton, 2004; Willis et al., 2004). 2,4-D, dicamba, and mecoprop are not recommend for application to newly seeded tall fescue until after the second mowing due to potential injury. herbicides are often required for more complete
Due to the contact activity and minimal grass injury from bromoxynil and carfentrazone, they potentially could be used during seeded establishment of tall fescue. They would be further beneficial in controlling broadleaf weeds that escape an application from siduron or quinclorac. Herbicides that are normally safe on established turf can induce phytotoxic effects when applied to seedling turf. Research was conducted to assess turf-type tall fescue tolerance to carfentrazone and bromoxynil integrated with siduron and quinclorac into potential weed management system scenarios for seeded establishment.

\section{Materials and Methods}

Research was conducted at the East Tennessee Research and Education Center-Plant Science Unit in Knoxville, Tenn., in 2004 and 2005. Three separate experiments were initiated on 24 Mar. 2004, 6 Sept. 2004, and 7 Apr. 2005. Experiments 1 and 2 were conducted on an Etowah silt loam soil (fine-loamy, siliceous, semi-active, thermic Typic Paleudults) and Expt. 3 was conducted on Sequatichie silt loam soil (fine-loamy, siliceous, semi-active, thermic Humic Hapludults). All field preparation and cultural practices were kept consistent for the experiments. Previous vegetation was killed with two applications of glyphosate (2.2 $\mathrm{kg} \cdot \mathrm{ha}^{-1}$ ) applied 8 and 3 weeks before seeding. Soil was tilled to a $25 \mathrm{~cm}$ depth and disked until the seedbed was smooth and fine. Soil was cultipacked, dragged with a harrow rake to remove dead vegetation, and further firmed by rolling with a smooth roller.

Experiments were seeded with 'Kittyhawk' turf-type tall fescue at $293 \mathrm{~kg}$ pure live seed/ha. Starter fertilizer $(6 \mathrm{~N}-10.5 \mathrm{P}-9.9 \mathrm{~K})$ was applied at a rate of $200 \mathrm{~kg} \cdot \mathrm{ha}^{-1}$. Seed were broadcast applied in two directions to insure uniformity, lightly dragged with a leaf rake in two directions, rolled with a smooth roller to provide further firming, and covered with a germination blanket (A.M. Leonard, Piqua, Ohio). Trials were irrigated twice daily with approximately $0.5 \mathrm{~cm}$ of water to maintain adequate surface moisture for germination. The germination blanket was removed at $14 \mathrm{~d}$ after seeding (DAS). In all cases, seed emerged $7( \pm 1)$ DAS. Biweekly mowing at 7 to $8 \mathrm{~cm}$ was initiated between 21 and 24 DAE.

All trials were fertilized 14 and 28 DAS at $200 \mathrm{~kg} \cdot \mathrm{ha}^{-1}$ with $24 \mathrm{~N}-2.7 \mathrm{P}-9.9 \mathrm{~K}$ fertilizer, after which no additional fertilizer was applied. Beginning 14 DAS trials were irrigated at $0.7 \mathrm{~cm}$ once daily for 4 weeks, and then were irrigated as needed to supplement rainfall events.

Experiments were arranged in a randomized complete block design with four replicates. Experimental units were $2.25 \mathrm{~m}^{2}$. Herbicide applications were made with a $\mathrm{CO}_{2}$ pressurized spray system calibrated to deliver 280 $\mathrm{L} \cdot \mathrm{ha}^{-1}$. The spray boom used four flat fan nozzles (model 8002XR; Spraying Systems Co., Wheaton, Ill.) with $25 \mathrm{~cm}$ spacing. Tall fescue was not mowed one day before and two days after treatment. Tall fescue injury and groundcover were visually rated for both 
experiments using a 0 to 100 scale. For tall fescue injury, $0 \%$ equals no visual injury and $100 \%$ equals complete plant death. To facilitate discussion, $\geq 20 \%$ injury was deemed as unacceptable injury due the potential detrimental effect on eventual turfgrass groundcover. For tall fescue groundcover, $0 \%$ equals no tall fescue turf present and $100 \%$ equals complete tall fescue groundcover. Groundcover was not rated in the first experiment due to intense smooth crabgrass competition in the nontreated plots. Weed competition was minor in other experiments. Weed species spectrum varied among experiments; therefore no weed control data are presented.

Herbicides treatment rates and timings are listed in Table 1. All quinclorac treatments applied $35 \mathrm{DAE}$ included $0.6 \% \mathrm{v} / \mathrm{v}$ methylated seed oil (MSO) (MSO concentrate contains $100 \%$ methylated seed oil and emulsifying surfactants; Loveland Industries, Greeley, Colo.) according to herbicide label recommendations (BASF Corporation, 2004).

Data were subjected to ANOVA using SAS (Cary, N.C.) $(p=0.05)$. Injury ratings for nontreated plots were not included in the analysis to decrease variance heterogeneity. Separate experiments were analyzed as environments within the ANOVA and the treatment by environment interaction was used as the error term by which the treatment effect was tested (McIntosh, 1983). Means were separated using Fisher's protected LSD $(p=0.05)$.

\section{Results and Discussion}

Treatment by environment interaction for tall fescue injury and groundcover was not significant $(p>0.05)$, therefore all data were pooled over experiments. Quinclorac at 0.84 $\mathrm{kg} \cdot \mathrm{ha}^{-1}$ applied at seeding was more injurious 14 DAE than siduron (Table 1). Quinclorac injured tall fescue seedling $27 \%$ compared $\leq 9 \%$ injury from siduron. Askew et al. (2003) reported no injury from quinclorac or siduron applied at seeding. Quinclorac has been reported to delay kentucky bluegrass (Poa pratensis L.) cover up to 16 weeks when applied at seeding, however no visual injury to the kentucky bluegrass was reported (Reicher et al., 1999). Siduron has been reported to be safe on tall fescue, kentucky bluegrass, creeping bentgrass (Agrostis stolonifera L.), and other cool-season turfgrass species when applied at seeding (Kerr 1969; Moshier et al., 1976).

Quinclorac applied as sequential applications at $0.84 \mathrm{~kg} \cdot \mathrm{ha}^{-1}$ was more injurious 42 DAE than single applications at 0.84 and $1.68 \mathrm{~kg} \cdot \mathrm{ha}^{-1}$ (Table 1). Similarly, quinclorac plus carfentrazone applied as a tank-mixture was more injurious $42 \mathrm{DAE}$ than quinclorac applied alone at either rate or quinclorac plus bromoxynil. Bromoxynil and carfentrazone alone treatments or following siduron at seeding applications injured tall fescue minimally $(\leq 6 \%)$. Turfgrass tolerance of various species to bromoxynil and carfentrazone has been previously reported. Taylor et al. (2004) reported excellent tolerance of common bermudagrass, 'Tifway' bermudagrass (Cynodon dactylon (L.) Pers $\times C$. transvaalensis Burtt-Davy), centipedegrass [Eremochloa ophiuroides (Munro) Hack], and 'Raleigh' st. augustinegrass (Stenotaphrum secundatum (Walt.) Kuntze) to carfentrazone at four times the rate used in our studies. Willis et al. (2005) and McElroy et al. (2004) reported tolerance of 'Riviera' seeded bermudagrass [C. dactylon (L.) Pers] and 'ThermalBlue' hybrid bluegrass ( $\mathrm{Poa}$ pratensis $\times P$. arachnifera Torr.), respectively, to carfentrazone at 0.015 and $0.03 \mathrm{~kg} \cdot \mathrm{ha}^{-1} \mathrm{ap}-$ plied during seeded establishment.

No information is available to explain the increased injury induced by quinclorac plus carfentrazone compared to quinclorac or carfentrazone alone treatments. Johnson (1996) reported greater large crabgrass [Digitaria sanguinalis (L.) Scop.] control with MSMA plus quinclorac compared to MSMA or quinclorac alone treatments at similar rates, suggesting a potential increased herbicidal activity when quinclorac is tank-mixed. MSMA and quinclorac are both active on large crabgrass. In contrast, carfentrazone is not active on grasses; thus, the tank-mixture comparison is not equivalent. The authors hypothesize that carfentrazone could slow quinclorac metabolism within tall fescue or the carfentrazone formulation could increase absorbance of quinclorac by tall fescue. Regardless of potential physiological effects attributing to increased injury, quinclorac plus carfentrazone did not decrease turfgrass cover 42 DAE. In fact, only quinclorac sequential applications reduced tall fescue turf cover 42 DAE.

Injury from quinclorac sequential applications and quinclorac plus carfentrazone applications persisted at 49 and 63 DAE. Injury from these treatments was normally an epinastic twisting of the foliage with no visual chlorosis or necrosis of the plant tissue. Despite injury from the herbicides, turfgrass cover was equivalent to the nontreated 49 and 63 DAE. Siduron $\mathrm{fb}$ bromoxynil was the only treatment to decrease turfgrass cover $49 \mathrm{DAE}$, despite minimal injury from this treatment across all rating dates. Sherman et al. (1980), however, reported siduron applied at rates 6.8 to 40.8 $\mathrm{kg} \cdot \mathrm{ha}^{-1}$ at seeding reduced seedling emergence, increased the number of abnormal seedlings, and increased the time required to reach complete establishment. The authors wish to note that Sherman et al. (1980) is an exception to the majority of other reports. Excellent safety on tall fescue, kentucky bluegrass, creeping bentgrass, and other cool-season turfgrass species following siduron at seeding applications has been previously reported (Kerr, 1969; Moshier et al., 1976). Further, excellent bromoxynil safety has been reported on established 'Tifway' bermudagrass, centipedegrass, st. augustinegrass, and seashore paspalum (Paspalum vaginatum Swartz), as well as seedling bermudagrass (Askew et al., 2004; Havlak et al., 2003; Lawson et al., 2002; Unruh et al., 2002).

Carfentrazone and bromoxynil can be used at or after 35 DAE of tall fescue seedlings with little injury and no delay in turfgrass groundcover. Increased injury should be expected when tank-mixing quinclorac and carfentrazone or bromoxynil, however, injury from quinclorac plus carfentrazone is more severe. Further, while injury from siduron fb bromoxynil did not occur, a delay in tall fescue cover can result from this weed control strategy.

\section{Literature Cited}

BASF Corporation. 2004. Drive 75DF herbicide. BASF Corp., Agr. Products, Research Triangle Park, N.C.

Askew, S.D., J.B. Beam, and W.L. Barker. 2003.

Table 1. Percent tall fescue injury and subsequent plant cover as influenced by herbicide treatments applied at seeding or $35 \mathrm{~d}$ after emergence (DAE). ${ }^{2}$

\begin{tabular}{|c|c|c|c|c|c|c|c|c|c|}
\hline \multirow[b]{2}{*}{ Herbicide $^{y}$} & \multirow{2}{*}{$\begin{array}{c}\text { Rate } \\
\left(\mathrm{kg} \cdot \mathrm{ha}^{-1}\right)\end{array}$} & \multirow[b]{2}{*}{ Timing } & \multirow{2}{*}{$\frac{14 \mathrm{DAE}}{\text { Injury }}$} & \multicolumn{2}{|c|}{$42 \mathrm{DAE}$} & \multicolumn{2}{|c|}{$49 \mathrm{DAE}$} & \multicolumn{2}{|c|}{$63 \mathrm{DAE}$} \\
\hline & & & & Injury & Cover & Injury & Cover & Injury & Cover \\
\hline Quinclorac & 0.84 & $35 \mathrm{DAE}$ & & 13 & 78 & 14 & 86 & 8 & 95 \\
\hline Quinclorac & 1.68 & $35 \mathrm{DAE}$ & & 10 & 82 & 14 & 86 & 12 & 95 \\
\hline Quinclorac fb quinclorac & $0.84 \mathrm{fb} 0.84$ & At seeding $\mathrm{fb} 35 \mathrm{DAE}$ & 27 & 24 & 76 & 24 & 85 & 17 & 93 \\
\hline Siduron & 6.7 & At seeding & 9 & 2 & 77 & 0 & 84 & 0 & 97 \\
\hline Carfentrazone & 0.017 & $35 \mathrm{DAE}$ & & 2 & 83 & 1 & 84 & 0 & 97 \\
\hline Carfentrazone & 0.034 & $35 \mathrm{DAE}$ & & 1 & 79 & 0 & 84 & 0 & 96 \\
\hline Bromoxynil & 0.28 & $35 \mathrm{DAE}$ & & 0 & 82 & 1 & 83 & 0 & 97 \\
\hline Bromoxynil & 0.56 & $35 \mathrm{DAE}$ & & 1 & 81 & 1 & 83 & 0 & 96 \\
\hline Quinclorac plus carfentrazone & $1.68+0.034$ & $35 \mathrm{DAE}$ & & 25 & 79 & 26 & 83 & 16 & 93 \\
\hline Quinclorac plus bromoxynil & $1.68+0.56$ & $35 \mathrm{DAE}$ & & 11 & 80 & 13 & 82 & 12 & 95 \\
\hline Siduron fb carfentrazone & $6.7 \mathrm{fb} 0.034$ & At seeding $\mathrm{fb} 35 \mathrm{DAE}$ & 9 & 6 & 81 & 2 & 81 & 0 & 97 \\
\hline Siduron fb bromoxynil & $6.7 \mathrm{fb} 0.56$ & At seeding $\mathrm{fb} 35 \mathrm{DAE}$ & 5 & 2 & 78 & 0 & 74 & 0 & 96 \\
\hline NonTreated & --- & -- & & & 83 & & 86 & & 98 \\
\hline LSD & & & 3 & 3 & 6 & 4 & 9 & 3 & NS \\
\hline
\end{tabular}

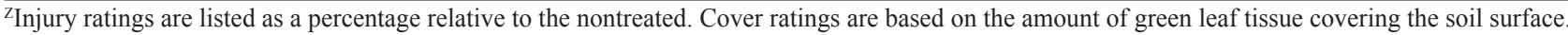

$\mathrm{Y}_{\mathrm{fb}}=$ followed by.

NSNonsignificant. 
New herbicide options for seeding cool-season turfgrass in spring. Proc. S. Weed Sci. Soc. $56: 85$.

Askew, S.D., J.B. Beam, and W.L. Barker. 2004. Weed control during bermudagrass seedling establishment. Proc. S. Weed Sci. Soc. 57:117.

Baughman, R.G., M.S. Virant, and R.A. Jacobson. 1981. Crystal and molecular structure of herbicides. IV. Bromoxynil. J. Agr. Food Chem. 29:989-991.

Bean, B.W. and M.W. Rowland. 2001. Grain sorghum weed control with carfentrazone-ethyl. Proc. S. Weed Sci. Soc. 54:16.

Dayan, F.E., S.O. Duke, J.D. Weete, and H.G. Hancock. 1997. Selectivity and mode of action of carfentrazone-ethyl, a novel phenyl triazolinone herbicide. Pestic. Sci. 51: 65-73.

Gannon, T.W. and F.H. Yelverton. 2004. Virginia buttonweed control in bermudagrass with carfentrazone and sulfonylurea herbicides. Proc. S. Weed Sci. Soc. 57: 107.

Grossman, K. 1998. Quinclorac belongs to a new class of highly selective auxin herbicides. Weed Sci. 46:707-716.

Grossman, K. and J. Kwiatkowski. 2000. The mechanism of quinclorac selectivity in grasses. Pesticide Biochem. Physiol. 66:83-91.

Havlak, R.D., W.G. Menn, W.J. Grichar, et al. 2003. Evaluating herbicidal injury to sod forming turfgrasses in sod production. Proc. S. Weed Sci. Soc. 56:91.

Johnson, B.J. 1996. Tank-mixed postemergence herbicides for large crabgrass (Digitaria sanguinalis) and goosegrass (Eleusine indica) control in bermudagrass (Cynodon dactylon) turf. Weed
Technol. 10:716-721.

Kelly, S.T., T.B. McKnight, D.K. Miller,A.L. Perrit, and D.R. Lee. 2002. Evaluation of carfentrazone for weed control in cotton. Proc. S. Weed Sci. Soc. 55:15-16.

Kerr, H.D. 1969. Selective grass control with siduron. Weed Sci. 18:181-186.

Lawson, R.N., J.B. Unruh, and B.J. Brecke. 2002. Lawn burweed (Soliva pterosperma) control in hybrid bermudagrass (Cynodon dactylon $\times C$. transvaalensis) and common centipedegrass (Eremochloa ophiuroides). Weed Technol. 16:84-87.

McElroy, J.S., P.D. Hahn, G.K. Breeden, and J.C. Sorochan. 2004. Weed control options for seeded hybridbluegrass (Poapratensis $\times$ P. arachnifera) establishment. ASA-CSSA-SSSA Annu. Mtg. Abstr.(available on CD-Rom).

McIntosh, M.S. 1983. Analysis of combined experiments. Agron. J. 75:153-155.

Mitchell, H.R. and E.V. Gage. 2000. Carfentrazoneethyl for control of broadleaf weeds in southern rice. Proc. S. Weed Sci. Soc. 53:168-169.

Moshier, L., A.J. Turgeon, and D. Penner. 1976. Effects of glyphosate and siduron on turfgrass establishment. Weed Sci. 24:445-448.

Reddy, K.N. 2001. Broadleaf weed control in ultra narrow row bromoxynil-resistant cotton (Gossypium hirsutum). Weed Technol. 15:497-504.

Reddy, K.N. 2004. Weed control and species shift in bromoxynil- and glyphosate-resistant cotton (Gossypium hirsutum) rotation systems. Weed Technol. 18:131-139.

Reicher,Z.J., D.V. Weisenberger, and C.S. Throssell. 1999. Turf safety and effectiveness of dithiopyr and quinclorac for large crabgrass (Digitaria sanguinalis) control in spring-seeded turf. Weed Technol. 13:253-256.

Robinson, B.L., S.B. Clewis, J.W. Wilcut, J.L. Corbett, and M. Paulsgrove. 2002. Broadleaf weed control with Liberty, Staple, Roundup Ultra, and Buctril. Proc. S. Weed Sci. Soc. 55:4.

Sherman, R.C., E.J. Kinbacher, and K.A. Reierson. 1980. Siduron effects on tall fescue (Festuca arundinacea) emergence, growth and high temperature. Weed Sci. 28:194-196.

Taylor, J.M., J.D. Byrd, Jr., and K.C. Hutto. 2004. Turfgrass tolerance and weed control with carfentrazone. Proc. S. Weed Sci. Soc. 57:116.

Unruh, J.B., B.J. Brecke, and L.E. Trenholm. 2002. Tolerance of seashore paspalum (Paspalum vaginatum) to common turf herbicides. Proc S. Weed Sci. Soc. 55:61.

Vencill, W.K. (ed.). 2002. Herbicide handbook. 8th ed. Weed Sci. Soc. Amer., Lawrence, Kans.

Warren, Jr., L.S. and F.H. Yelverton. 2004. Viola species control using sulfonylurea herbicides. Proc. S. Weed Sci. Soc. 57:94.

Willis, T.G., L.B. McCarty, and A.G. Estes. 2004. Postemergence control of parsley-piert (Aphanes arvensis) and wild garlic (Allium vineale) in dormant bermudagrass (Cynodon dactylon). Proc. S. Weed Sci. Soc. 57:95.

Willis, J.B., D.B. Ricker, and S.D.Askew. 2005. Carfentrazone, quinclorac, and trifloxysulfuron effects on seeded bermudagrass establishment and crabgrass control. Proc. N.E. Weed Sci. Soc. 59:65.

Zawierucha, J.E. and D. Penner. 2001. Adjuvant efficacy with quinclorac in canola (Brassicanapus) and turfgrass. Weed Technol. 15:220-223. 